\title{
Contemporary Song Folklore of the Kazakhs of the South-West Zhetysu: The Experience of Musical and Regional Research
}

\author{
B.Z. Babizhan*, A.R. Berdibay, A.B. Baisakalova, Y.T. Chukmanov and A.N. Ulkenbaeva
}

Kurmangazy Kazakh National Conservatory, Almaty, 90, Abylai Khan Avenue, 050000, Kazakhstan

\begin{abstract}
Kazakh music and dance has many unique features but also has many things in common with the music and dance of Mongolia and Central Asia. For Kazakhs the summer has traditionally been the best time for merry-making. They often sing and dance during summer nights on the pastures. The relevance of the study is due to the insufficient study of the Kazakh song folklore of the south-western part of Zhetysu, represented by eight districts of the borderland of Almaty and Zhambyl regions with Kyrgyzstan. This article is aimed at identifying the genre composition of the song folklore of the local tradition, the conditions of its existence, as well as the peculiarities of their musical-poetic structure and musical language. The results of this research are a contribution to the musical archeology of Kazakhstan. They can also be used in the study of the stylistic originality of the song folklore of the Kyrgyz and Uzbeks living in the border regions of Kazakhstan and Kyrgyzstan.
\end{abstract}

Keywords: Ritual folklore, Folk song, Qaraöleñ (traditional Kazakh poetry), Musical and stylistic features, Region, Genre, Culture, Tradition.

\section{INTRODUCTION}

In the statement of the researcher of the Mongolian song K. Yatskovskaya (1988) stated that: "The fate of the folk song was to become the keeper of artistic traditions, to convey to us the aesthetic ideal, the image of the indivisibility of the world, which was born among the nomads of Central Asia" contains the idea of the integrity of the understanding of the world of the peoples of a large geographic region, to which, as you know, the Kazakhs belong. And if the understanding of the picture of the world, the relationship of the individual with the Cosmos, expressed by the means of traditional poetics, were generally national in nature, the musical embodiment of artistic and poetic images was carried out in a variety of regional styles.

The question of the regional belonging of the samples of musical-poetic, instrumental and dance genres of traditional art and the reasons for their emergence is one of the frequently discussed in the ethnographic sciences. Thus, the ethnomusicologist V. Shchurov (2013) believes that "national musical culture is formed from the totality of local traditions. Possessing integrity, monolithicity, it at the same time unites various, sometimes sharply contrasting phenomena. When clarifying the reasons for the formation of local traditions in each specific case, it is necessary to take into account the aggregate diverse historical, economic, natural and other factors that

*Address correspondence to this author at the Kurmangazy Kazakh National Conservatory, Almaty, 90, Abylai Khan Avenue, 050000, Kazakhstan; Tel: 87474112082; E-mail: abahman.aa@yahoo.com contributed to the cultural consolidation of people in that or another region and thereby contributed to the emergence of separate forms of traditional creativity. A similar idea about the importance of regional styles in the formation of national song art and the prerequisites for their emergence is expressed by the researcher of folklore B. Putilov (1994). The author writes: "Traditional folk culture in its specific content is always regional and local. Its natural, normal life is tied to the life of a certain, limited by one or another framework, a collective, is included in its activity, it is necessary for it and is regulated by its characteristic social and everyday norms. Since the ethnic collective occupies a certain historically formed space, which has its own geographical, natural and other characteristics, then its traditional culture is regional both in the historical, social and spatial terms".

Noticing at the beginning of the 20 s of the last century, the conditioning of the regional musical features of Kazakh songs with the landscape of the area, climatic conditions of nomadism, and other conditions, the famous musical ethnographer $A$. Zataevich (1963) wrote: "beautiful landshats, Akmola and Semipalatinsk provinces, picturesque mountains, fast streams and rivers, green groves and bird forest hubbub - all this finds an undoubted echo in the rhythmic and figurative revival of the songs of East Kazakhstan, in their melodic flowery and inclination to virtuoso.Not so in the songs of western and southwestern Kazakhstan (Bukeevskaya province and Adayevsky district). Endless plains, desert saline steppes, poverty of flora and fauna, dull monotony of a flat and low-lying sea coast - all this adjusts to 
lingering, pensive and dull songs". Also, the prominent Russian scientist K. Kvitka (1973) drew attention to the question of the conditionality of regional types of oral musical and poetic heritage by types of natural and economic conditions, who believed that: "Kazakhs live on a vast territory, representing various conditions for the economy. Obviously, their work provides a lot of material for study in connection with the characteristics of different parts of their ethnic area".

The next group of scientists, agreeing with researchers of the older generation about the historical, geographical and economic prerequisites for the emergence of regional styles, is designated as one of the important factors in the formation of local styles of society. Thus, the famous researcher of the song folklore of the Slavs V. Goshovsky (1964), who called local styles "musical dialects" in this regard, wrote that they arise "over the centuries in connection with historical, socio-economic and geographical conditions, as well as a result of the interaction of various tribes ethnic groups "within the people and the mutual influence of two neighboring peoples, and the prominent Kazakh scientist B. Karakulov (2019), who studied the regional modal aspects of Kazakh traditional songs, believed that" the reasons that determined local musical characteristics, in addition to musical development patterns, are also sociallyhistorical phenomena, among which ethnogenetic processes played a leading role.

It is known that musical and regional studies on folklore in Kazakhstan began to appear starting from the 1960s of the 20th century. Domestic scientists initiated the study of different locations of the country (A. Temirbekova, T. Bekhozhina, B. Karakulov, A. Kunanbaeva, K. Tuleutaev, G. Baitenova, B. Turmagambetova, B. Muptekeyev, etc.) and abroad (K. Zhuzbasov, O. Musakhan). Different generations of ethnomusicologists were lucky to collect and study the richest oral song heritage of the Kazakh people in Taldy-Korgan, East Kazakhstan, Kyzylorda, Karaganda, North Kazakhstan, West Kazakhstan and other regions, as well as in the Altai Territory of the RSFSR and Mongolia. Cardinal changes in sociohistorical development and consciousness at the end of the last century, as a result of which the republics of the former Soviet Union became sovereign states, their transition to a new economic formation, which led, along with a number of innovations, and the implementation of the next stage in the development of science and the discovery of new methods of study, as well as the accumulation of field material, determined new vectors for the development of the sphere of regional studies in domestic ethnomusicology. And therefore, the opinion of a specialist in song folklore Zhetysu, its discoverer - A. Temirbekova(1975) that "The original songwriting of the Kazakhs of Semirechye has been little studied until now. Meanwhile, their musical folklore is rich and unique"expressed more than forty years ago about the specific features of the musical culture of this region in the contest of the entire republic, has been actualized at the present time, since its vast territory, consisting of more than 20 districts (225 sq.km), needs in-depth study, which determines the regional aspects of the study.

In this regard, the purpose of this article is to consider the musical and stylistic features of the samples of folk song genres of folklore in the southwestern part of Zhetysu. Its solution involves the solution of such tasks as:

1. Description of the geographical location of Zhetysu;

2. A brief overview of the main historical milestones;

3. History of study of Zhetysu by ethnomusicologists;

4. Analysis of musical and poetic samples.

The object of research is the folk song tradition of the south-west of Zhetysu, the subject of study is the musical-poetic structural and musical features of songs.

Hypothesis 1: The formation of an original style of song folklore in the southwest of Zhetysu is conditioned by socio-historical, geographical, economic and economic conditions;

Hypothesis 2: Song folklore of the southwest of Zhetysu is a transitional type of musical dialect.

Historical and geographical characteristics of the object of study: Zhetysu (from the Kazakh "zheti" - seven and "su" - water), a historical-geographical region, the southeastern part of Kazakhstan between lakes Balkash in the north, Sasykkol and Alakol - in the southeast, the ridges of the Northern Tien Shan - in the south. The name Zhetysu comes from the 7 main rivers of this region: Ile, Karatal, Bien, Aksu, Lepsy, Baskan, Sarkan (Kazakhstan, 2005).

Its southwestern part is represented by several districts of two adjacent regions: Karasai and Zhambyl districts - Almaty, and Kordai, Shuisky, Merke, Ryskulovsky, Baizak, as well as Moyynkum districts - 
Zhambyl regions. On the north side, this geographic space has a common border with Karaganda (SaryArka), in the east - with other districts of Almaty, in the west - Zhambyl regions. In the south, this region borders on Kyrgyzstan. The main types of household management are pasture and semi-nomadic livestock raising and agriculture.

"Natural conditions favorable for economic management have made Zhetysu one of the centers of ancient civilization in Central Asia. In the Paleolithic, Neolithic and Bronze Age, they were engaged in land cultivation, hunting, fishing, mining ore, smelting iron, social relations developed, signs of patriarchal family property appeared.The Great Silk Road passed through Zhetysu, the appearance of which influenced the vectors of cultural development in this region"(Kazakhstan, 2005).In the VI-XI centuries in the south-west of Zhetysu, agriculture, blacksmithing and handicraft flourished, and relations with Sogd and Shash expanded. Various cities of the Shuya valley during this time period were the capitals of the Western Turkic Kaganate and the Karakhanids. In 1129-30 Karakitai (Khitan) invaded Zhetysu and soon mixed with the local population. Zhetysu became one of the centers of the Karakitai state. In the XIII century here from Altai and Mongolia came the Naimans and Kereis, displaced from their places by Genghis Khan. Since 1218 , the territory of the south-west of Zhetysu was subordinated to his son - Chagatay.

After the disintegration in the middle of the XIV century on this territory of the Chagatai ulus in the eastern part of the Chagatai ulus, the rulers of the Duglat (Dulat) tribes formed a new state of Mogolistan. It consisted of various Türkic and Türkized Mongol tribes, including the Duglat (Dulats), Kangly, Kereits (Kerei), Barins, Bulgachs, etc., who became known under the common ethnonym Moguls. And the XV century. and the beginning of the 16th century. They became part of the Kazakh and Kyrgyz peoples. In the middle of the fifteenth century. Kazakh khans Zhanibek and Kerey founded the Kazakh Khanate here.

In the XIV-XVI centuries here lived the clans that formed the basis of the Senior Zhuz of the Kazakhs. After almost a century domination of the Dzungars here, in the 2 nd half of the 18th century. Kazakh tribes returned most of Zhetysu. In the XIX century the Zhetysu lands south of lle were captured by the Kokand Khanate. "In 1960, Russian troops, together with the Kazakh horse militia, inflicted a crushing defeat on the troops of the Kokand Khanate near Uzunagash.
By the end of 1860, the Russian Empire completely subdued Zhetysu. In 1867, the Semirechensk (Zhetysu) region was created on the territory of Zhetysu. As a result of the national-state demarcation of the Soviet republics of Central Asia in 1924-25, the Zhetysu territory became part of Kazakhstan and Kyrgyzstan" (Kazakhstan, 2005).

According to natural-geographical, historical, economic and other conditions, scientists subdivide this territory into northeastern (from Lake Balkash, in the north to the Ketpen and lle Alatau ridge in the south, from the Shu-lle watershed in the west to Lake Alakol in the east) and south -western (valleys of Shu and Talas) part (Kazakhstan, 2005).

Most of the representatives of sciences related to ethnomusicology considered the regional features of the eastern and western parts of Zhetysu autonomously (Ch. Valikhanov, A. Sabitov, A. Dosymbaeva, P. Voyakin), and some in comparison with each other $(\mathrm{O}$. Korbe) or in the context of intraregional and interregional relations (O. Nakysbekov). At the same time, the material of the study of the eastern part of the region was subdivided inside itself into northeast and southeast.

The works of historians and archaeologists testify to the existence of centers of ancient culture on the Zhetysu land, the emergence of artifacts of which is due to deep ideological and ethical attitudes. Thus, the historian A. Dosymbaeva (2010), who studied the ideological foundations of sacred medieval monuments in the southwestern part of Zhetysu, wrote: the marker of which was the river Shu itself, which is a symbol of one of the deities of the Turkic pantheon - Zher/Su Earth/Water. From the north-east of the territory of the Zhaisan sanctuary, the Kindiktas mountain range adjoins, which means "stone-umbilical cord", The semantic interpretation can be interpreted as "the center of the Turkic land". In the northwestern part, the Zhaisan valley is surrounded by the Khantau mountains, i.e. Khan Mountains. The toponym "auliekora", translated as a sacred abode, is the name of the area that is located within the sacred space of the Zhaisan sanctuary". Also, one of the sacred places of our territory is the architectural and archaeological complex of the 8th-9th centuries in the Zhambyl region, which is $40 \mathrm{~km}$ away. east of the city of Taraz. With regard to the unique unfinished palace complex Akyrtas (literally "the last stone") in the Zhambyl region (the beginning of construction - V-VIII centuries), presumably built for local Turkic rulers, reconstructed 
by a group of designers (A. Nabiev, L. Nurkusheva, K. Suleimanov, G. Sadvokasov and Zh. Imanbaev), several versions of the appointment have been put forward, including their Buddhist, Nestorian, Muslim (Arab) roots (International Journal of innovative technology and Exploring Engineering).

The works of ethnographers who turned to the study of Zhetysu in the middle of the last century are of great interest for studying the existence of the traditional culture of this region in the Zhambyl region.

One of them is an article by O.A. Korbe (1950), written in the early 50 s of the XX century and dedicated to the 30th anniversary of the Kazakh SSR is devoted to the description of rural life - the types of farming, dwelling, its interior decoration, clothing, family lifestyle of the southeastern and southwestern regions of Zhetysu. So, the object of the author's research was a number of collective farms in the Kegen region of the Almaty region, as well as the Chui region of the Zhambyl region. As the author wrote: "in many regions of Kazakhstan, the remnants of tribal stratification still persist. On the territory of the southeastern part of the republic live mainly members of four large clan associations of the Senior Juz (Zhuz is a historically established association of Kazakhs. In total, 3 zhuz were formed: Senior Zhuz, Middle Zhuz and Younger Zhuz) - Alban, Suan, Jalair and Dulat, which split into a number of small generic divisions - "ru". Considering the types of dwellings, its interior decoration, clothes of men and women in different age stratification, the scientist discovers in the culture of the two parts of Zhetysu common and special. So, according to the author, a new type of residential building - brick-uy began to spread in the collective farm "Belbasar" (south-west of Zhetysu) "in their type, these new residential buildings are similar to the southern Russian and Ukrainian dwellings"and in the Kegen district there is an interesting type of headdress for girls - takhia, which is a round hat with a solid base, covered with red kumach, and common with coins, beads, buttons. Often, a sultan made of owl feathers is sewn to the tachia, which in the past played the role of a talisman, and now is perceived as a common decoration. In the Kegen district, in some places, as an addition to the festive outfit, wide leather belts of beldik, decorated with metal plates and chasing, have been preserved as an addition to the festive dress. Among the related features, the researcher noted that the interior decoration of the dwelling of collective farmers in both the Chui and Kegen districts traditionally goes back to the decoration of the yurt, from where it passed into a modern residential building, having received a new application.

Almost simultaneously with the previous author, an ethnographic study of one of the regions of the southwestern part of Zhetysu was carried out by the scientist N. Sabitov. Unlike O. Korbe, in his work, an ethnographer pays attention to the genres of Kazakh folk art and their figurative themes, to the instruments that functioned at that time in the Kazakh aul. Among them, along with the main instrument (dombra), which functions both solo and in an ensemble with singing, the ethnographer calls the mandolin and the violin, which indicates the continuation of the process of penetration of European instruments into the Kazakh culture.

Describing the oral musical and poetic heritage of the Kazakhs of the Merken region, the author wrote that: "The theme of oral folk art has radically changed. You will no longer hear old songs related to nomadic and semi-nomadic life. Collective farmers sing songs that reflect the life of collective farms, social production, as well as songs about the Great October Socialist Revolution, about the Great Patriotic War. Most of the songwriters are ordinary collective and collective farmers, tractor drivers, combine operators, teachers, etc." Also, N. Sabitov (1953) recorded the rituals of the maternity and funeral rituals.

The stability of the patriarchal customs described by the author, as you know, determined the long-term preservation of spiritual culture, namely, musical and poetic genres. And this is confirmed by their publication in the musical and ethnographic collections of the last decades. A particularly vivid and expressive phenomenon of the oral musical heritage is the folkprofessional art (änşi, küyşi, jırşhı) made it possible to differentiate the southwest of Zhetysu from its other geographical parts. And this reveals the commonality of scientific interests of ethnomusicologists and representatives of related sciences.

Of undoubted importance for musical and regional ethnomusicological studies is such a branch of linguistics as dialectology. By definition, placed in the "Great Soviet Encyclopedia", dialectology is "a department of linguistics that studies dialects. When analyzing a dialectal language in its territorial variation, all linguistic features - phonetic, grammatical, derivational, lexical - are considered in the system. The elements are common, characteristic of all dialects, and distinctive, available only in some of them. 
Dialectal differences are the main object of the study of dialectology. A hierarchy of dialectal differences relating to different levels of the language system, their place at this level, the interaction between levels are established". Similarly, the object of study in ethnomusicological research, and in particular in works on song culture, appears as a system consisting of musical and poetic subsystems, the structure and specific features of the hierarchical levels of which function in interconnection within themselves and between these subsystems.

Among the works on dialectology devoted to the study of the southwestern part of Zhetysu, the monograph of the linguist O. Nakysbekov (1972), the content of which was the result of studying the materials of expeditions in 1950-60, is of great interest to musical archeologists in a number of districts of Alma-Ata and Zhambyl regions. As the author writes: "The proposed work is devoted to the study of the language of the Kazakhs living in the territory washed by the Chu River, in the border area with Kyrgyzstan and have long had close cultural and economic close ties with it; determination of the peculiarities of the local dialect in relation to the Kazakh literary language and other local dialects".

The study outlines the geographical area of the study. These are the Kordai, Moinkumsky, Shuisky, Merkensky and Lugovsky districts of the Zhambyl region, having a common border with the Uzynagashsky district of the Almaty, Shetsky and Zhanaarkinsky districts of the Karaganda region, as well as with the Chuisky, Panfilovsky districts of the Kyrgyz Republic. This shows that the area chosen for the study of the whole coincides with the musicalethnographic zone, the models of spiritual culture that became the material of ethnomusical analysis. $O$. Nakysbekov (1972) attaches great importance to the emergence of the Shui dialect in terms of geographical and historical preconditions. According to the author, the emergence of local peculiarities was due to the influence of neighboring peoples with the Kazakhs, cultural and economic ties with which they had a sufficiently long history. Therefore, the original linguistic features of the Kazakhs in the Zhetysu West, unconditionally, became the result of the influence and influence of the Kyrgyz and Uzbek languages. The influence of Uyghur historical songs, which arose as a result of the resettlement of parts of the Uyghur in the Semirechye in 1881-1883, is also excluded (Alibakieva, 1988).
The position of the author on the geographical location and historical ties of this region with others (and not always with them borderline) is especially important for understanding the reasons for the emergence of the Kazakh musical dialect of the Yugoslav people, Zhetysu.

Before approaching the presentation of the main content, it is necessary to stop at some questions of pre-study of this topic.

Musical and poetic patterns of the native tradition began to be recorded by musical ethnographers in the 20th century the last century. Well-known collector of Kazakh traditional music A.V. Zatayevich (1963) recorded about a dozen songs of Zhetysu, which were placed in the section "Turkestan" in the collection "1000 songs of the Kazakh people". A large contribution to the collection and study was made by a prominent scientist B.G. Erzakovich (1982), who wrote from the representative of the folk-professional tradition of Kenena Azerbayeva, is one of the few examples of rite folklore. An important work on the study of song folklore was carried out by the researcher $A$. Temirbekova, the material of the dissertation, which were the songs of the north-eastern part of Zhetysu (Temirbekova, 1975). Significant ethno-musical achievements in the field of gathering and publication of songs and poems Zhetysu became musical and ethnographic collections: "Zhetysu melodies" (Kuzbakova, 2012) and "Zhetysu tunes"(Kuzbakova, 2012). The work of other researchers was dedicated to the study of the border areas of Zhetysu with Central Kazakhstan (Tuleutaev, 1989) and the musicalrecitative tradition of the North-East Zhetysu (Bekmuratova, 2015).

Computer research of dombra structures, including its eastern type, which belongs to the Zhetysu region, conducted by S. Utegalieva(2016).

However, the object of study of this article - the song tradition of the south-western part of Zhetysu has never been considered in the above-mentioned works.

\section{MATERIALS AND METHODS}

The main research methods were complex, structural and comparative typological methods that contribute to a deep disclosure of the socio-historical, geographical and cultural prerequisites for the emergence of song folklore South-West Zhetysu; poetic and musical structure, the main melodic types of 
his samples in the context of their intraregional and interregional connections.

According to the concept of the famous ethnomusicologist E. Gippius (1982): "The most common identifying features of each regional song system are: a) the composition of genres, b) hierarchical forms of their interrelationships in relation to the centralizing genre of each song system, c) types of tunes in specific forms determined by this genre system intonation and groups of poetic texts associated with them". Therefore, the systematization of the song material was started by the authors of the article precisely with the identification of genres that exist in the area under study. To clarify the dynamics of the development of local song genres and carry out comparative research, along with the materials of folklore expeditions of the last two years, examples of this and neighboring regions, collected and published in the last quarter of the previous century and the beginning of the current century, were also used.

Material collected by researcher B. Babizhan during expeditions in 2018 and 2019. from Zhambyl and Kaskelensky districts of Almaty, and Kordai, Shu, Merke, Moyynkum, Ryskulovsky and Baizak districts of Zhambyl region consisted mainly of examples of nonritual folklore ("qara öleñ”, "xat-öleñ”, "besik jırı", "arnaw"). Among the ritual genres (representing a smaller part of recorded folklore samples), samples of wedding ("sıñsw", "qızdıñ zhar-zharı", "toybastar") and calendar ("zharapazan") rites were recorded. Unfortunately, the researcher did not manage to record examples of the ritual of saving a person or an animal from a disease - "bädik" and "baksı sarını", which in the last century managed to catch the famous musical ethnographers and researchers A. Zataevich and B. Erzakovich.

Comparison of the genre composition of the material recorded by $\mathrm{B}$. Babizhan in this region with the folklore recordings of her colleagues-predecessors indicates a greater stability of the functioning of nonritual folklore, namely, "Qara öleñ". It is the central and most developed layer of the west zhetysu song folklore. As well as the untimely lyric songs of some ethnic groups, "their out-of-ritual intonation, and some other signs indicate that this genre belongs to a rather late stylistic layer of tradition (Belogurova\&Smirnova, 2015).

And according to the degree of their prevalence, the Zhetysu songs "Qara öleñ" can be rightfully placed on a par with the everyday songs of the Kazakhs of
Mongolia (and distinguished from the song tradition of the western part of the country, for example, the Aktobe region). Likewise, in comparison with the collection "Zhetisu Huenderi", the material of which was collected at the end of the last century and covered mainly the eastern regions of Zhetysu, in the song samples of the southwest there were much more songs of presumably late origin, as well as songs that had a nationwide distribution.

The respondents were mostly older women of the Botbai and Zhanys subdivisions of the Dulat clan, but there were also ethnophores from the clans of the Middle and Younger Zhuzes, as well as representatives of other Turkic-speaking ethnic groups (Kyrgyz, Uyghurs, Uzbeks) who not only knew the language of the indigenous population well, but and partly owned his folklore repertoire. For the most part, all of them were daughters-in-law of the elder zhuz clans and, following the partially preserved patriarchal foundations, acted as keepers of their spiritual traditions.

The geographical location of the regions of the studied region and the historical past explains the distribution in them of a number of songs that are performed in Central and South Kazakhstan, in the northeast and southeast of Zhetysu. Among the recorded Kyrgyz songs, those that are better known mainly in the border area - Chui and Talas regions of Kyrgyzstan, were repeated.

The diversity of the repertoire of ethnophores from the families of the Middle and Younger Zhuz may be due to historical events that determined the process of migration from Central, Eastern and Western Kazakhstan. During the years of gaining sovereignty in the south-west of Zhetysu, compatriots from near and far abroad began to resettle. For example, in Merkensky district of Zhambyl region, dozens of families of Kazakhs from Karakalpakstan moved here, close to the style of Western Kazakhstani songs, a musical and ethnographic collection of which was composed in 2019 by researcher K.Kairulla. At the same time, the representatives of the Younger Zhuz, the ancestors of those who moved here in different periods of the past centuries, as well as womenrespondents who grew up married to local young people, performed as fast as the west. Musical and poetic models of the genus Middle Zhuz (Argin) are mostly performed in the Moiynkum district, which has a common border with the Karaganda region. 
In the process of the expedition, the respondents often performed songs with exactly repeated and improvised poetic texts to the melodies of such wellknown (and included in a number of public) models. The content of the lyrics of such a song often contained the title and description of the specific place and situation of performance. In some cases, the words of the song "Qara öleñ" were addressed to the most collector of folklore - B. Babizhan, that is, the poetic text was improvised by respondents directly in the process of singing. Among the models, the content was dedicated to the expression of philosophical thoughts about the shortness of life, as well as the appeal to girls, relatives, loved ones, etc. It is interesting to note that a number of songs from the south-west of Zhetysu are performed with the words of such popular songs from other regions, such as "Jorğatay", "Gül-gül”, "Bekzatım-ay"but only on other melodies.

Most of the respondents did not attach importance to the names and did not in any way denote the intonated folklore samples of everyday songs, as a result of which, when deciphered, if these were wellknown songs, they were labeled $B$. Babizhan by the name of their melodies. Also, as it is widespread in song practice in all other regions of the country, in some cases songs received their names according to the words of the chorus additions, refrains, or one fragment at a time (the words of the first or last syllable of the first line, according to the text of the last line, etc.) parts of the song. The main reason that the respondents did not focus on the names of the songs seems to be the improvisation of the poetic text. As you know, everyday songs "Qara öleñ" are usually performed at the guest table at various festivities or when meeting at the dastarkhan (set table) of relatives, neighbors and friends. "The content of such songs in this regard often depends on the composition of the audience and the type of their relationship. And in view of the fact that their main function was to recreate a special communication between people, their spiritual comfort, peers often exchanged songs with humorous content among themselves, a man with his wife's younger sister, a woman and her husband's younger brother, a man and his sister's son, that is, in such cases, representatives of different ages and social and family status sang. The situation of the execution of "Qara öleñ", as it were, "leveled" them (Babizhan, 2018).

Experience of folklore expeditions in 2018-2019 allowed to draw the attention of researchers to songs, the main part of the structure of which repeats the melody of an already known song, and the chorus is improvised both according to the poetic text and the melody. For example, the main part of Dedication to the beloved" was performed by the respondent $\mathrm{N}$. Kaltaikyzy to the melody "Karakozim" popular in Zhetysu. stacked in a traditional style. The performer's extraordinary creative abilities and a large repertoire (which also includes Kyrgyz songs for her own text) allowed her to introduce an updated section into the melody of a famous song, the musical and stylistic features of which were in harmony with the previous section of this song.

In the southeast of Zhetysu, songs from regions that are not in the immediate vicinity have also survived, or songs from one of the southern regions are performed in other regions of this vast region (Turkestan, Zhambyl also - parts of the Kyzylorda, Almaty regions are located in the south of the country). For example, the West Kazakhstan song "Aktolgai" has spread in the Kyzylorda, Turkestan (South Kazakhstan), Zhambyl and Almaty regions, i.e. on the territory of those regions that until the 60s of the XIX century. were part of the Kokand Khanate. The existence in modern times of melodies of the same songs in the musical culture of four regions located in the southern part of Kazakhstan can be explained by close historical, economic, sociotribal and other relationships. The same prerequisites can determine the reasons for the lack of popularity of West Kazakhstan songs in the east, southern songs in the north and vice versa. Due to the geographical location between the west and east and favorable conditions for farming, building cities and trade routes, and other reasons, migration of the population in different historical periods from one part of the country to another, presumably, earlier more often passed through its southern part. And therefore, it is no coincidence that the route of the railway - the TransSiberian Railway, built in the second half of the 1920s of the XX century, also stretched from Semey to Arys through the lands of Zhetysu.

In folklore expeditions in the southwest of Zhetysu, there were respondents who sang Kyrgyz songs and improvised texts to their famous melodies. More often this happened in the settlements where both Kazakhs and Kyrgyz live, and also there are inter-ethnic marriages. The most common Kyrgyz songs were found in the area under study: "Narynnan khat" (Letter from Naryn) and "Sary oi" (name of the area). Similar to the facts obtained during the linguistic expeditions of the middle of the last century, the process of interaction between the two cultures continues in the present. The 
popularity of some Kazakh songs among the Kyrgyz, and vice versa, is due not only to the close geographical location and kinship of linguistic and confessional factors, but also to long-term goodneighborly and kinship relations. In the conditions of gaining independence, both countries go through similar stages of socio-historical and cultural development. In the musical art of our time, along with folklore parallels, this is reflected in the common style in mass culture.

Along with songs common with other regions, in the south-west of Zhetysu there are original samples that have never been recorded by musical ethnographers before and have not become widespread in its eastern regions. If the previous group of songs, due to their belonging to different regions, characterized this region as a transitional one as a whole, then in the original style of West Zhetysu songs the intertwining of dialectal features of songs from different regions is manifested at the level of individual means of the musical language. Also, in terms of the intonation-rhythmic and structural organization of most of them, close ties with local folk-professional songs are found.

The expedition records contain examples in which the locality, the name of the genus are marked, and a brief description of its known representatives is given. So, for example, in the chorus of the song "Susamıreldiñ jaylauı" is sung - a summer mountain pasture located on the territory of Kyrgyzstan, to which Kazakh clans climbed. According to the classification of the researcher M. Matlin, who studied the cultural landscape, similar songs belong to one of the types of localization, deduced "by the presence of names of geographical objects in the lyrics of songs" (Maltin, 2009).

A large number of arabic songs have survived among the people. They often narrate about the forced labor of an arbakesh-carter, about his thoughts, about loneliness"(Baigaskina, 2019). In Kazakh oral traditional poetics, the image of a horse of different colors is more characteristic, which was likened to the "wings" of a horseman.

The analysis of musical and poetic samples collected in expeditions to the south-west of Zhetysu was carried out in comparison with the examples recorded by scientists from local respondents in the $X X$ - beginning of the present century, as well as in comparison with the songs of the southeast of the region recorded by $\mathrm{B}$. Muptekeyev in the last decades of the last century. The absence of recordings of song folklore in the borderlands with China and East Kazakhstan over the last twenty years makes it possible to consider traditional songs of the western and eastern parts of the region only in a diachronous aspect.

From all the material collected during the expeditions of 2018-2019 researcher B. Babizhan (2018) has now notated and published in the musical and ethnographic collection of about 70 songs, approximately one quarter of which are variants of 3-4 songs. The volume of material recorded by the older generation of researchers from the respondents in the southwestern part of Zhetysu is about 20 samples.

\section{RESULTS}

The ethnomusicological study of the song folklore of the southwestern part of Zhetysu led to the appeal of the authors of the present to the works of related sciences: history, ethnography and linguistics, whose representatives, in the context of their specificity and to varying degrees, studied the regional features of different parts of Zhetysu.

And many of the provisions on Zhetysu, derived by representatives of related branches of knowledge, found their confirmation in this ethnomusicological research. So, for example:

1) the ideological foundations of Kazakh culture, captured in the monuments of the early Middle Ages and the characteristics of the area as the center of unification of all three zhuzes in the 16th century. reflected in the content of the poetic texts of the songs that have survived and are present here today and in their great stylistic diversity.

2) The last of the named features of Western Zhetysu songs also correlates with the research of the linguist $O$. Nakysbekov, who defined the local dialect as "transitional".

3) Articles by ethnographers $\mathrm{O}$. Korbe and $\mathrm{N}$. Sabitov reveal the features of the material and spiritual culture of the Kazakhs of the eastern and western parts of Zhetysu, the dynamics in their vitality.

4) The need to identify the local features of research subjects in the culture of the Kazakhs of the East and West of Zhetysu led to the fixation by historians, ethnographers and linguists of the facts 
of the clan affiliation of local Kazakhs, as well as their systematic connections and interactions with other clans and ethnic groups.

5) In this regard, respondents from the Botbai and Zhanys clans of the Senior Zhuz were more often noted in the folklore expeditions of B. Babizhan. Their repertoire was mainly local (Zhetysu), as well as South Kazakhstan and Arka (Central Kazakhstan) songs. At the same time, here, in the southeast of Zhetysu, there were songs that are widespread in its eastern part, in which other clans of the Senior Zhuz live - Alban, Suan, etc. In the Moyinkum district, bordering in the Karaganda region, along with representatives of the Senior Zhuz, live and natives of the clans Arkyn and Uak of the Middle Zhuz. Here, more often than in other districts of the studied region, both folklore and folk-professional songs of Central Kazakhstan were encountered. Respondents who are not related to the Elder Zhuz, whose ancestors lived in this territory in previous centuries or who came from other regions and created their families here in 1950-1960, also mastered the local repertoire of folk songs. Representatives of the clans of the younger Zhuz who moved from Karakalpakstan to the Merke region during the period when the country gained sovereignty, brought their songs with them and had not yet managed to master the locals.

6) During the expedition, local Kazakh everyday songs were also recorded from ethnophores of other Turkic ethnic groups (Kyrgyz, Uighurs, Uzbeks), and the local population also has Kyrgyz songs in its repertoire, i.e. here the processes of interaction and mutual enrichment of different Turkic musical cultures take place.

7) The bulk of the respondents were elderly women.

8) the dominant genre was the genre of the Kazakh everyday song - "Qaraöleñ".

9) In the poetic texts of some of them, there were such artistic images that are not widespread in other regional traditions. These include "arba" and "tea".

10) In terms of the poetic size and musical and poetic forms of songs, the west of Zhetysu does not differ from the musical and poetic examples of other regions in the country. However, local folk songs can be distinguished from others by the frequent use of the eleven-syllable variety: $4+4+3$; according to some refrain words; by internal methods of shaping, when the one-line chorus at the end of the song is often duplicated. The musical form of the main part of the solo in a number of samples has a one-element structure: AA.

11) In the intonation-melodic system of songs in Western Zhetysu, the initial types are important: $d$ $e-g, c-d-e-d-e-g, d-e-f i s-g, d-g-a-h-d$.

Examples of initial intonation types of songs in the southwest of Zhetysu:
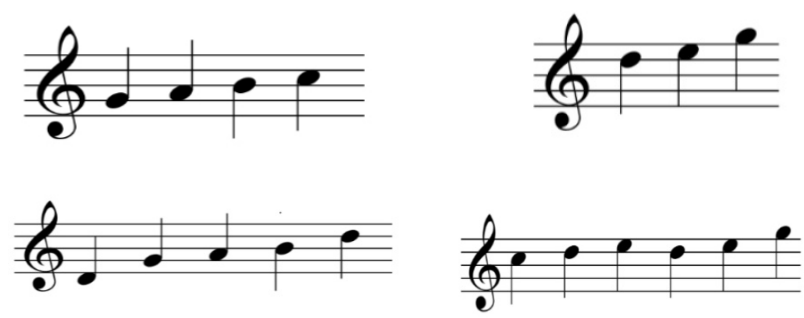

Figure 1: Sample notes.

Among the final intonation types, the following are more common: $d-c-a-g ; a-g-a-g ; c-b-a-g ; h-a-g$, etc.12) In terms of rhythmic organization, one-way lines are widespread: $7+4$, as well as uncensored types of small lines. As a rhythmic figure that clearly identifies the style of local songs, we can name two sixteentheighth, eighth, eighth, the initial part of which is often combined with its inversion: the eighth or two sixteenths.

\section{DISCUSSION}

Among family ritual genres, songs of the ritual of seeing off the bride "Sıñsw", female "zhar-zhar", "toybastar"have been preserved in western Zhetysu. From the calendar songs - "zharamazan" is performed.

As researcher A. Baigaskina (2019) writes: "the most widespread genre of the wedding cycle are songs of brides farewell to relatives and native places. The recordings of this ritual testify to the fixed rhythmic formality - a calm alternation of uniform syllables of mostly seven- and eight-syllable verses, where the last syllable of each line is drawn in (six eighths - one quarter or seven eighths - one quarter). Ethnomusicologist G. Kuzbakova (2012) identifies two types of farewell songs of brides according to the typurhythmic and formal organization, the first type of 
"SIñsw" is ritualistic, the second is ritual in terms of poetic content, lyrical in terms of expression, which is associated with the interaction of ritual genres with lyric

- "Qara öleñ”.

Two examples of "Sıñsw" recorded in the expedition of recent years, in their musical specificity, belong to the first type named by G. Kuzbakova. "Sıñsw", recorded by $\mathrm{B}$. Babizhan, as well as other regional examples of the same name, are based on the 7-8 complex scale of versification and have the form of a musical-poetic stanza. According to the rhythmic organization, the first of them shows a one-way type of strings, which is also often found in examples of the same name in other regions.

The lines of the second are an uncensored type of rhythmic organization, more characteristic of musicalrecitative genres (Babizhan, 2018).

In terms of musical content, the first "Sıñsw" from the materials of the expedition in 2018. B. Babizhan is related to the sample recorded in the southeast of Zhetysu (Muptekeyev\&Medeubekuly, 2008), but unlike the second (sing-chorus), it has a non-singing form (The complication of the musical and poetic structure can also be observed in the East Suu"zharapazans").

In terms of the scale organization in the western version, it is a hexachord (I-II-III-IV-V-VI), while in the East-Suu "Sıñsw"the scale is a transitional type (expansion of the pentatonic scale by adding the sound of the VII scale and sub-quarter tone).The initial intonation type "Sıñsw": $d$-e-fis- $h$ is more often found in "Qara öleñ"of the eastern regions of Zhetysu, but in the latter this intonation type is more often used at a different pitch, namely, as: $g$-a- $h$-e.

Researcher A. Baigaskinais characterized by "zharzhar". In the following image: "Girls and young men, representing the sides of the bride and groom, are exchanged for verses. The first sing about a woman's share in a foreign family, the melody of the couplets carries a sad character. The couplets of the young are more optimistic, although the rhythmic formula is identical. The female "zhar-zhar" develops in the range of the quintet of the minor inclination. Eleven-syllable verses with ritual chants form two melodies of the question-answer content".

Two models of "Kızda rzhar-zharu", recorded in the Merkensky district of Zhambyl region, are similar in content, but different in their poetic text. It is necessary to pay attention to the fact that in the second verse of the original pattern the text of the household song is used, while the content of the first verse is within the framework of the wedding ceremony. Also, as in the female "zhar-zhar" of other regions, the poetic size of the Merkens variant represents its 11 th compound with words - "zhar-zhar".

Poetic size of women's “jar-jar”:

$4+3+4(3)$

$4+3+4(3)$

$4+3+4(3)$

$4+3+4(3)$

The musical structure is a one-element 4-line (or semistrophic) form, two lines of which are in the ratio "divergence from identity" (AA1):

A $a b c(d)$

$A 1 a b$ e (f) :\|

Each of the rhythmic lines is a one-piece construction, which is typologically common to other regions as well. The second recorded example in musical form is a two-element stanza:

$A a b c(d)$

B e f e $(g): \|$

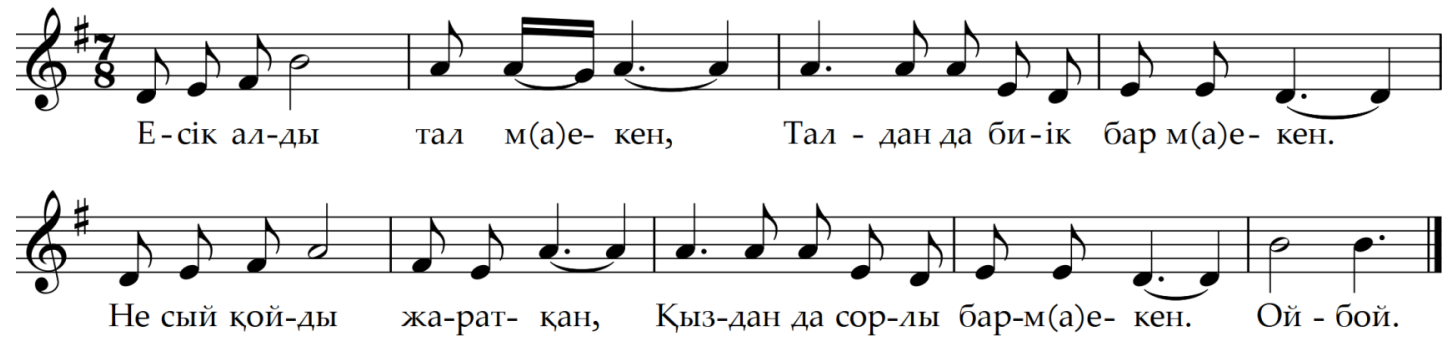

Figure 2: "Sıñsw". 
Thus, if in the first "zhar-zhar" stage the sound organization is realized in the form of the same beginning of two lines with their divergence in the reference, then the two-line form of the second sample is realized on the basis of two intonationally autonomous constructions. The first "zhar-zhar"begins with an ascending fourth leap and its subsequent filling, in the second the melodic movement is based on an ascending third turn. The end sections of odd lines end in IV, even ones - in I steps. A similar ratio of the endings of small lines is shown by an example of a Kyrgyz bride's farewell, based on the lonian mode:
The genre of calendar rituals "zharapazan" was represented by one type. "These songs (zharamazan) are peculiar forms of folk musical creativity, distinguished by cheerful, cheerful intonations, rooted in the pre-Islamic period. Their prototypes were probably old carols-songs, congratulatory-magnifying nature, which became a new part of the repertoire with the widest sphere of existence (Abdullaev, 2006). Since Zhetysu is currently an area of distribution, mainly of everyday songs, that is, "in hierarchical forms of interconnection of genres in relation to the centralizing genre" (Muptekeyev \& Medeubekuly, 2008)

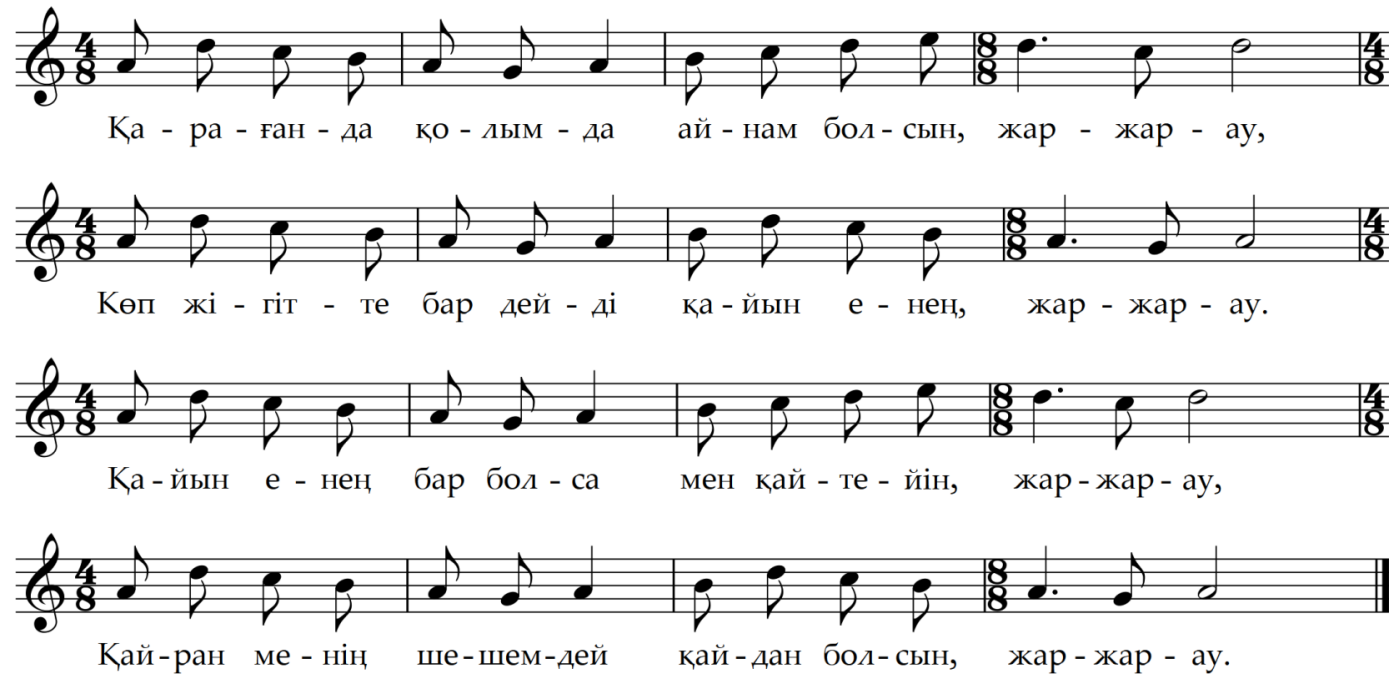

Figure 3: "Sıñsw".

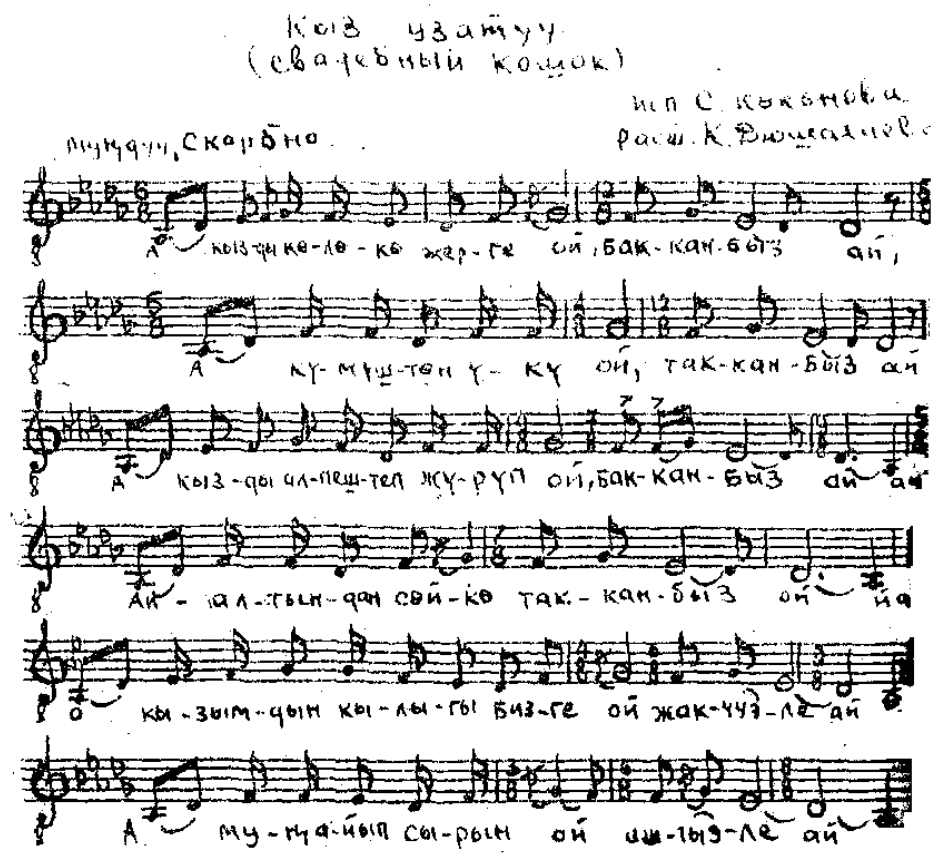

Figure 4: Note example of Kyrgyz "Sıñsw" (Dyushaliev, 2019). 
"zharamazan", like a number of other genres, is significantly influenced by musical specifics "Qaraöleñ". This close connection is found both in comparison with the intonational type of the beginning of the song: g-ah-d with a specific sample, and at the level of the size of versification, musical-poetic form, scale, rhythmic organization, the features of which are generally characteristic of "Qara öleñ" Zhetysu. It is interesting that "Zharapazan" reported to A. Zataevich by $O$. Zhandosov almost a hundred years ago also resembles "Qara öleñ", however, compared with the samples of recent expeditions, it is built on the basis of a different modal-intonation system, the initial melodic turnover of which: $b-c-d-g$ is related to the song "Guldar-ai", recorded by B. Muptekeyev in the eastern part of the region.

A significant part of the Western Zhetysu singingchorus lines in terms of musical and poetic structure, everyday songs are semi-strophic and full-strophic forms (a structure consisting of 2, and full-strophic - of 4 musical-poetic lines). Semi strophic show one (AA) and two-element structure $(A B)$. Full strophic can be based on both $(A B A B)$ and three elements ( $A B C C$, AABS ...). At the same time, in the region under study, songs are often found in the form of which the principle of "divergence from identity" is used, i.e. in which only the initial part of the lines exactly matches (AA1). Paired lines similar in form to the principle can be found in both semi-strophic and full-strophic forms. Choruses often appear in the form of chorus additions, appearing as the endings of semi-strophes.

A distinctive feature of the West Zhetysu folklore samples of songs collected in recent years from oriental and local samples collected in the 20th century is the greater distribution of examples in the Aeolian mode, which, apparently, can be explained by the strong influence of modern mass music (As the musical notation of the last century, songs with melodies based on the mentioned fret were much less common). One of the typical examples is "Wide-breasted two-year-old horse" (Babizhan, 2018). The name of the song comes from the words of the chorus addition. The poetic text of the love-lyric content of two verses is usually performed with the famous song "Bekzatym-ai" (A characteristic that is endowed with a person with the best qualities). The melody "Kaska tos kunanym-ai" was also widespread thanks to its popularization by the prominent akyn-termeshi AyazBetbaev (Iskakov, 2020).

The g-fret is characteristic of all local Aeolian songs. In view of the fact that in the musical transcriptions of songs and musical recitations of prominent representatives of the folk-professional tradition of the western part of Zhetysu (Suyunbai, Zhambyl, Kenen, etc.), which have become the style guidelines of the local song tradition, there are almost no tunes in the Aeolian mode, in the songs of the low it is more difficult to find the characteristic features of the local song tradition at the basis of the mood. Therefore, the above-mentioned modal support is one of the important features of modern Zhetysu songs. Single-causal lines with the isolation of the last syllable 11 of a complex line with an internal structure: $4+3+4$ are also among the local characteristics of the analyzed song.

Expeditionary discoveries 2018-2019 The studied tradition of Zhetysu became songs by little-known professional folk authors. Among the author's (folkprofessional) songs of the south-west of Zhetysu, KaltayAndabaev's song "Xällilillättim" (refrain word) stands out clearly, which can be considered an example demonstrating interregional and interethnic musical and poetic ties. At the same time, it should be noted that the commonality (in terms of the figurative content, the size of versification, the principles of constructing a musical-poetic form, the modal system, intonation types and rhythmic formulas), confirming the interaction of traditions, can be found in other examples of the above group of songs.

\section{CONCLUSIONS}

Kazakh folk music instruments are classified by some into stringed instruments, skin instruments and breath instruments. The study of the musical and regional traditions of the vast territory of Kazakhstan and, specifically, the southwestern part of Zhetysu is an important scientific interest not only for domestic ethnomusicology, but also for the scientific community of Central Asia. Geographically, the southwest of Zhetysu in the north has a common border with Kyrgyzstan, and historically in the 19th century. The studied area belonged to the Syrdarya region, different areas of which were subsequently distributed between Kazakhstan, Uzbekistan and Kyrgyzstan. The language dialect of Kazakhs in the south-west of Zhetysu belongs to the group of southern dialects, most of which, as you know, were formed in the context of intercultural interaction of the peoples of Central Asia. The gradual extinction of the oral form of transmission of musical and poetic traditions, the departure from the life of their carriers enhances the relevance and puts scientists in front of the need to actively collect, fix and study the song folklore of this region. Materials of 
historical and archaeological sources subdivided Zhetysu into northeast and southwest; Russian ethnomusicological studies were devoted to the northeastern (A. Temirbekova, 1966) and southeastern parts of Zhetysu (B. Muptekeyev, 2010). For various reasons, the southwestern and northwestern parts of Zhetysu remained outside the attention of ethnomusicologists for a long time.

And although global socio-historical events of the 20th - early 21 st centuries left their mark on the state of spiritual traditions, the partial preservation of the type of economic structure and patriarchal consciousness led to the stable functioning of ritual and non-ritual layers of Kazakh song folklore in the south-west of Zhetysu.

Nevertheless, a comparative analysis of the available musical samples allows us to draw some conclusions:

Expeditions of recent years to the southwestern regions of Zhetysu indicate the gradual fading of the tradition of performing ritual folklore and the widespread distribution of songs of the non-ritual layer. At the same time, the analysis of examples of song folklore of Kazakhs of the south-west of Zhetysu reflects the processes of musical interaction of ritual and non-ritual folklore with each other.

Non-ritual songs can be classified into sample types:

1. Became widespread (nationwide), thanks to historical and cultural prerequisites and modern means of communication (Ay, säwlem, Şhïli özen, Äy-äy böpem, Şhınar-ay, Bekzatım-ay, Bir bala, Kerim-au ayday, Gülderayım, Gül-gül jayna, Güldärïğa, Abaykök, Qoğalı-ay,Aqtolğay, Külända etc.);

2. Executable in other parts of Zhetysu (Kümis qumğan, Dedim-ay-aw, Büldirgen, Bes kämpït, Ïğawjan, Qarağay etc.);

3. Representing only this local Zhetysu tradition (Arba keledi, Qara şhay işh, Qalampır, Qımizdı qızdarmenen, Mïwalı daraq-ay, Dom-dom,
Dirïdan, Nurlığayın, Öleñ-ğayıp, Ürï-soq, Ürïdan, Ağayın-twıs, Arnaw, Jan qalqa, Äy, ägay, Ey, Alla, Qasqa tös qunanım-ay).

\section{REFERENCES}

Yatskovskaya, K.N. (1988). Folk songs of the Mongols. Moscow: Science.

Shchurov, V. (2013). Style foundations of Russian folk music. Moscow: Contemporary Music.

Putilov, B.N. (1994). Regional/local origin in folklore.

Zataevich, A. (1963). 1000 songs of the Kazakh people. Moscow: State Music Publishing House.

Kvitka, K. (1973). Ethnographic distribution of pentatonic scale in the Soviet Union.

Goshovsky, V. (1964). Folklore and cybernetics. Soviet music, no 11, pp. 74 83. Moscow.

Karakulov, B. (2019). Musical symmetry. Almaty

Temirbekova, A. (1975). Kazakh folk songs. Almaty: Zhazushy.

Kazakhstan. (2005). National Encyclopedia, Almaty.

Dossymbaeva, A. (2010). The traditional worldview of the medieval Zhetysu Turks (based on cult monuments). Almaty.

International Journal of innovative technology and Exploring Engineering (IJITEE) (2019). Volume, 8 (10).

Korbe, O. (1950). Culture and everyday life of the Kazakh. Soviet ethnography, no 4,pp. 67-92.

Sabitov, N. (1953). Ethnographic expedition to the Merke district of the Dzhambul region. Soviet ethnography, no 3.

Nagysbekov, O. (1972). Transitional dialects of the Kazakh language Almaty: Gylym.

Alibakieva, T. (1988). Uygur Historical Songs, Moscow: "Soviet Composer". Retrieved from http://the_uighurs.tripod.com/Rus/RusHisSongs.htm

Utegalieva, S. (2016). Computer studies of the Kazakh dombra and kylkobyz tunings. Yearbook for Traditional Music, no 48,pp. 146-166. https://doi.org/10.5921/yeartradmusi.48.2016.0146

Gippius, E.V. (1982). Problems of areal research of traditional Russian song in the areas of the Ukrainian and Belarusian borderlands. Traditional folk music and modernity (typology issues). Moscow: GMPI named afterGnessin.

Belogurova, L.\& Smirnova, A. (2015). Lyrical songs of the mountain Mari: the art of transposition.

Babizhan, B. (2018). Song folklore of the Merke region. Almaty.

Matlin, M. (2009). Locally timed songs in the folklore space of the Ulyanovsk Volga region.

Baigaskina, A. (2019). Rhythm of the Kazakh traditional song. Almaty.

Kuzbakova, G. (2012). Kazakh ritual song. Rhythmic structure and semantics. Astana: Master Po.

Muptekeyev, B.\&Medeubekuly, S. (2008). Zhetysuawenderı. Almaty.

Dyushaliev, K. (2019). Kyrgyz folk songs, terme and dastans. Bishkek: Publishing house: Kerbez.

Abdullaev, R. (2006). Rite and music in the context of the culture of Uzbekistan and Central Asia. Tashkent.

Elemanova, S. (2000). Kazakh traditional song art. Almaty: Press.

Iskakov,Zh. (2020). "Sawıtbektıñsarqıtı - Ayaz akın". Almaty.

Erzakovich, B. (1982). Kazakh musical folklore, Almaty.

Tuleutaev, K. (1989). Balxaşöñiriniñänfolklorı. Almaty: Oner.

Bekmuratova, A. (2015). Musical and poetic traditions of akynsZhetysu. Almaty.

Received on 22-11-2020 Accepted on 31-12-2020

Published on 18-01-2021

\section{DOI: https://doi.org/10.6000/1929-4409.2021.10.16}

(c) 2021 Babizhan et al.; Licensee Lifescience Global.

This is an open access article licensed under the terms of the Creative Commons Attribution Non-Commercial License (http://creativecommons.org/licenses/by-nc/3.0/) which permits unrestricted, non-commercial use, distribution and reproduction in any medium, provided the work is properly cited. 